\title{
Two cases of Zika fever imported from French Polynesia to Japan, December 2013 to January 2014
}

S Kutsuna (sonare.since1192@gmail.com) ${ }^{1}$, Y Kato ${ }^{1}$, T Takasaki ${ }^{2}$, M L Moi ${ }^{2}$, A Kotaki ${ }^{2}$, H Uemura $^{1}$, T Matono ${ }^{1}$, Y Fujiya ${ }^{1}$, M

Mawatari ${ }^{1}$, N Takeshita ${ }^{1}$, K Hayakawa ${ }^{1}$, S Kanagawa ${ }^{1}$, N Ohmagari ${ }^{1}$

1. National Center for Global health and Medicine, Disease Control and Prevention Center, Tokyo, Japan

2. Department of Virology 1, National Institute of Infectious Diseases, Shinjukuku, Tokyo, Japan

Citation style for this article:

Kutsuna S, Kato Y, Takasaki T, Moi ML, Kotaki A, Uemura H, Matono T, Fujiya Y, Mawatari M, Takeshita N, Hayakawa K, Kanagawa S, Ohmagari N. Two cases of Zika fever imported from French Polynesia to Japan, December 2013 to January 2014 . Euro Surveill. 2014;19(4):pii=20683. Available online: http://www. eurosurveillance.org/ViewArticle.aspx?Articleld=20683

Article submitted on 19 January 2014 / published on 30 January 2014

We present two cases of imported Zika fever to Japan, in travellers returning from French Polynesia, where an outbreak due to Zika virus (ZIKV) is ongoing since week 41 of 2013. This report serves to raise awareness among healthcare professionals, that the differential diagnosis of febrile and subfebrile patients with rash should include ZIKV infection, especially in patients returning from areas affected by this virus.

We report two cases of Zika fever in Japan, which were imported from French Polynesia, where on 6 November 2013 public health authorities reported an outbreak of subfebrile illness with rash due to Zika virus (ZIKV). The epidemic started spreading across the archipelago beginning in week 41 of 2013 [1]. During weeks 42 to 52 , the syndromic surveillance network reported 6,630 suspected ZIKV infection cases to the Bureau de Veille Sanitaire. About 500 of these cases were tested at the Institute Louis Malarde laboratory in Papeete for confirmation; 333 were confirmed by real-time reverse transcription-polymerase chain reaction (RT-PCR) as ZIKV infections [2]. The outbreak is currently ongoing and as of 13 January 2014, 361 laboratory-confirmed

\section{FIGURE 1}

Conjunctivitis in a case of imported Zika virus infection from French Polynesia, Japan, January 2014

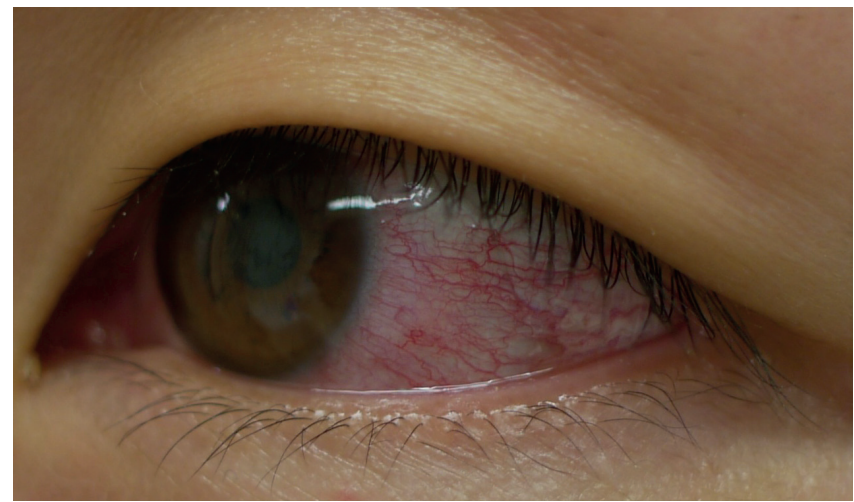

Although the patient was afebrile upon examination, both bulbar conjunctivas appeared congested. cases have been reported [3]. Symptoms of most ZIKV infection cases are mild and self-limited (mean duration of symptoms is 3-6 days). No hospitalisations for acute infection have been reported.

\section{Case 1}

A previously healthy Japanese man in his mid-20s presented to our hospital in mid-December 2013 after four days of fever (self-reported), headache, and arthralgia and one day of rash. He had visited Bora Bora in French Polynesia, in the first week of December 2013 for six days for sightseeing with his partner. He did not use insect repellent during the trip. Upon examination, his body temperature was $37.2^{\circ} \mathrm{C}\left(99^{\circ} \mathrm{F}\right)$ and he had maculopapular rash on his face, trunk, and extremities. Other clinical examination results were normal. Laboratory tests revealed leucopenia $\left(3,300 \times 10^{6} / \mathrm{L}\right.$; norm: $\left.3,500-8,500 \times 10^{6} / \mathrm{L}\right)$ and thrombocytopenia $\left(14,900 \times 10^{6}\right.$ /L; norm: $\left.15,000-35,000 \times 10^{6} / L\right)$. ZIKV RNA was detected in serum using real-time RT-PCR performed at the National Institute of Infectious Diseases in Japan with primer-probe sets previously described [4]; thus, we diagnosed the patient with Zika fever. His fever and other symptoms subsided a day after first presentation and his rash disappeared over the next few days.

\section{Case 2}

A previously healthy Japanese woman in her early $30 \mathrm{~s}$ presented to our hospital in the beginning of January 2014 for retro-orbital pain, slight fever (self-reported), rash, and itches. Her retro-orbital pain and mild fever had appeared five days prior to her visit at our hospital, while the rash and itches appeared on the day before the visit. She had travelled to Bora Bora where she stayed for 10 days starting mid-December 2013 for sightseeing with a companion. The first symptoms occurred six days after this journey. She had used insect repellent during her travels, but reported mosquito bites. She was afebrile and in good general condition at the first presentation to the hospital. On examination, both bulbar conjunctivas appeared 


\section{FIGURE 2}

Maculopapular rash on the back in a case of imported Zika virus infection from French Polynesia, Japan, January 2014

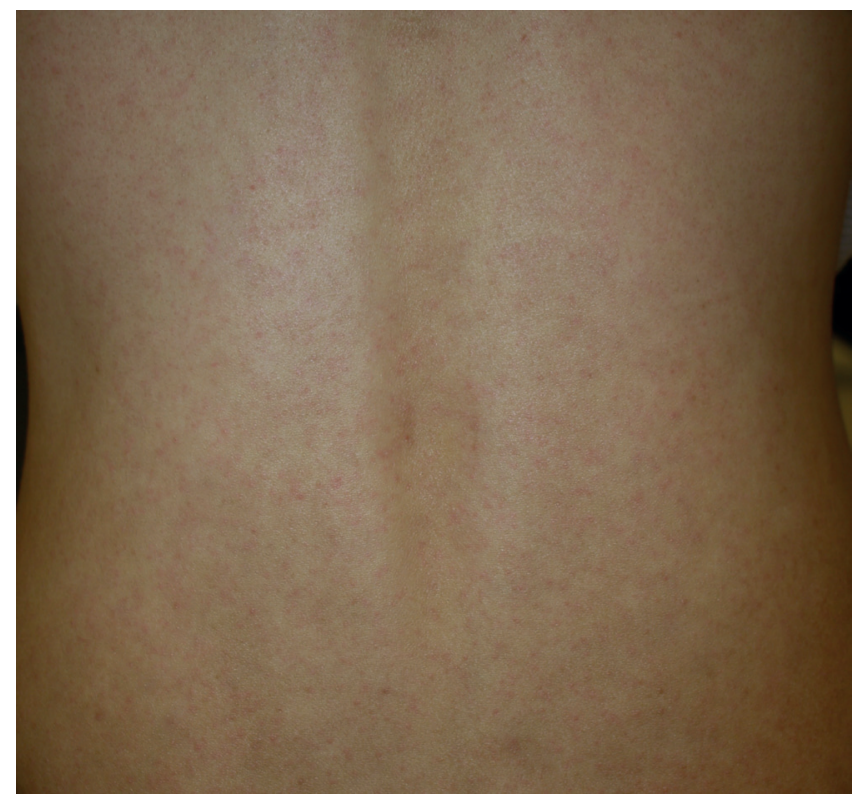

congested (Figure 1). She had maculopapular rash on her face, trunk, and extremities (Figure 2).

Laboratory tests on the day of first presentation at the hospital revealed leucopenia $\left(3,500 \times 10^{6} / \mathrm{L}\right.$; norm: $3,500-8,500 \times 10^{6} / \mathrm{L}$ ) and thrombocytopenia $\left(14,400 \times 10^{6} / \mathrm{L}\right.$; norm: $\left.15,000-35,000 \times 10^{6} / \mathrm{L}\right)$. Real-time RT-PCR assays, performed at the National Institute of Infectious Diseases, gave negative results for ZIKV RNA in serum but presence of the virus was detected in urine. The patient was diagnosed with Zika fever. Her leucocyte and platelet levels returned to the normal range 12 days after first presentation at the hospital. The positive versus negative ratios $(\mathrm{P} / \mathrm{N}$ ratio) of Zika-specific IgM antibodies were positive in two serum samples collected on the first day at the hospital and five days later $(\mathrm{P} / \mathrm{N}$ ratios $=2.4$ and 9.8 , respectively; ratios were considered positive when greater than or equal to 2.0). The neutralising antibody titres of the serum in these two consecutive samples were $\mathrm{PRNT}_{50}=1: 20$ and $\mathrm{PRNT}_{50}=1: 1,280$, respectively.

\section{Background}

Zika fever is a febrile or subfebrile illness caused by ZIKV, which mainly spreads through the bite of infected mosquitoes. ZIKV is a member of the family Flaviviridae, which includes dengue viruses, West Nile, and yellow fever viruses [5]. The most common symptoms reported in confirmed ZIKV infections are fever, headache, malaise, maculopapular rash, fatigue or myalgia, and arthritis and arthralgia [6].

ZIKV was first isolated from the blood of a sentinel rhesus monkey from the Zika Forest in Uganda [7]. Serological studies and isolation of ZIKV strains have subsequently demonstrated that the virus has a wide geographical distribution, including eastern and western Africa, south and south-east Asia, and Micronesia [8], where in 2007, an outbreak of Zika fever was reported on Yap Island [9].

\section{Phylogenetic analysis of the Zika virus sequence retrieved from case 2}

Phylogenetic analysis of the partial ZIKV E-protein genome sequence ( $470 \mathrm{bp}$, GenBank accession number: AB $908162^{*}$ ) obtained from the urine sample of case 2 , shows that this sequence has $99.1 \%$ identity with the sequence of a ZIKV strain isolated from Cambodia in 2010 (GenBank accession number: JN860885), and 97.9\% identity with the sequence of a ZIKV strain isolated in Yap islands in 2007 (GenBank accession number: EU545988) (Figure 3). The sequence from case 2 sample was also similar to previously identified ZIKV sequences of strains in Asia and Micronesia [8]. In the phylogenetic tree, these sequences formed a distinct cluster from that of sequences from Zika viruses of African origin. Further studies using full-length genome of the ZIKV will address the similarity between virus strains of the African and Asian clusters.

\section{Discussion and conclusion}

Our two cases are among the first imported cases found linked to the recent outbreak in French Polynesia starting in 2013. They occur shortly after 26 imported cases into New Caledonia from the same outbreak, as well as the report of one indigenous case [10]. Aside from cases related to French Polynesia, imported Zika fever cases have been previously identified in travellers returning from Africa and south-east Asia. These include a case of sexually transmitted Zika fever following two imported cases from Senegal into the United States, and an imported case of Zika fever from Indonesia to Australia $[11,12]$. Two imported cases from Thailand, one to Canada [13] and one to Germany [14] have also recently been reported.

Although the numbers of imported cases described so far are limited, the possibilities of ZIKV infections to be underdiagnosed and underreported are high due to generally mild symptoms and self-limited disease. Additionally, due to the similarity of ZIKV disease symptoms to those of dengue and chikungunya, differential diagnosis is required to define the extent of ZIKV epidemic. Importantly, as dengue virus (DENV) outbreaks also occur in French Polynesia [2], differential diagnosis between ZIKV infection and dengue is required in cases related to this area. Because of the ongoing dengue epidemic in Bora Bora, DENV infection was excluded in both cases in this study, by confirming that the serum samples were negative for both dengue virus nonstructural glycoprotein-1 (NS1) antigen and IgM/IgG antibodies, using rapid diagnostic kits (SD Bioline Dengue Duo Combo, Alere Medical, Inc.).

In this study, the two cases of ZIKV infection had not only leucopenia but also mild thrombocytopenia. 
Phylogenetic analysis of a Zika virus sequence derived from a case of imported Zika virus infection from French Polynesia, Japan, January 2014
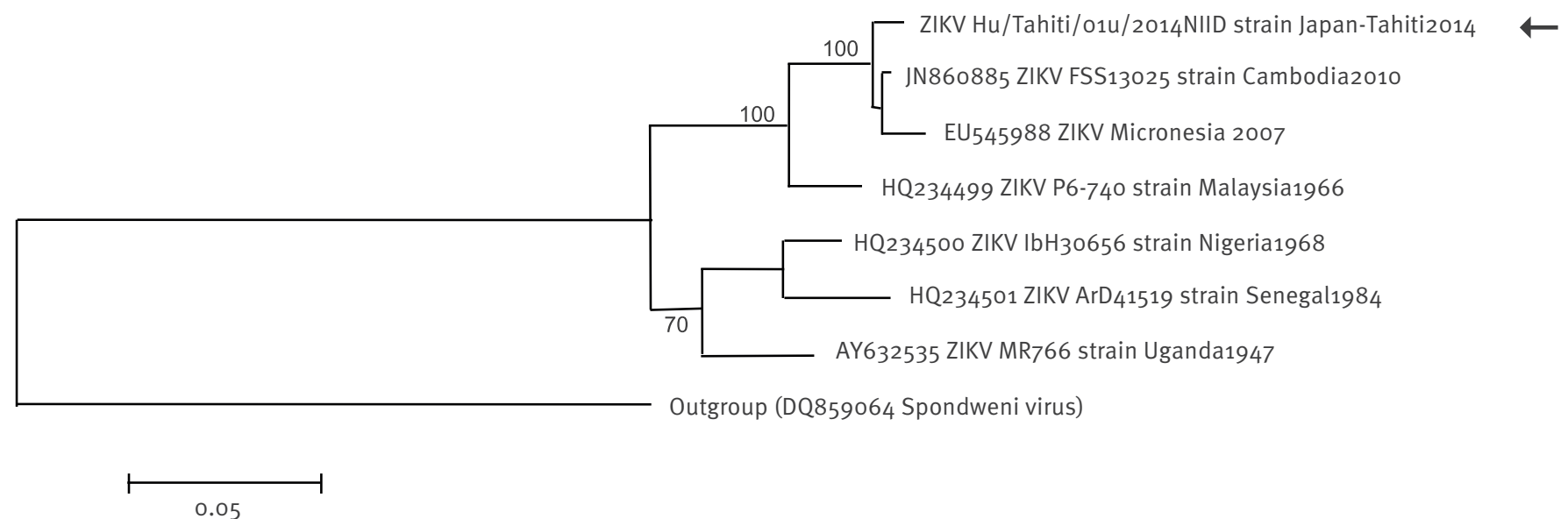

The phylogenetic tree was based on partial E-protein nucleotide sequences and compiled using the neighbour joining method (Genetyx, Japan). The sequence of the Spondweni virus (GenBank accession number D0859064) was used as an outgroup. Bootstrap percentages based on 1,000 replicates are shown on the tree nodes. The sequence of the case of imported Zika virus infection from French Polynesia to Japan in January 2014 is indicated with an arrow. Scale bar (0.05) indicates nucleotide substitutions per site.

Previous investigators reported leucopenia, but not thrombocytopenia in patients with ZIKV infection [12]. Our two cases suggest that ZIKV infection can be associated with clinical features including thrombocytopenia and leucopenia, and shares similar clinical features to those of dengue fever and yellow fever.

In the second case identified in this study, viral RNA was negative in the serum sample but was positive in the urine sample. To our knowledge, this is the first case diagnosed by detection of Zika viral particles in urine. Detection of DENV genome in urine after disappearance of the viral genome in serum samples by realtime RT-PCR has been a useful laboratory diagnostic method [15]. Our case suggests that detection of Zika virus genome in urine by real-time RT-PCR is useful to confirm ZIKV infection, particularly after disappearance of viraemia in serum.

Phylogenetic analysis revealed that the ZIKV genome sequences of case 2 , had a high sequence homology with recent strains from Asia and Micronesia, including those detected in Cambodia in 2010, but sequence homology was low with a strain isolated in 1947, the Ugandan prototype MR766 strain [4].

The ongoing ZIKV outbreaks in French Polynesia and the confirmation of ZIKV viraemic travellers in our study suggests that in addition to enhanced and continued surveillance efforts, awareness among healthcare professionals should be raised that ZIKV infection ought to be considered as differential diagnosis in febrile patients with rash returning from areas affected by this virus. Further prevention measures, such as offering advice on the use of insect repellents during travel to regions with outbreaks, would be important for ZIKV disease control.

\section{Acknowledgments}

This work was supported by funding from Research on Emerging and Re-emerging Infectious Diseases by the Ministry of Health, Labor and Welfare, Japan (H24-shinkouippan-013, H23-shinkou-ippan-010).

\section{Conflict of interest}

None declared.

\section{Authors' contributions}

Satoshi Kutsuna collected the data and drafted the manuscript; Yasuyuki Kato participated in the coordination and concept of the manuscript and edited the manuscript and helped with the draft of the manuscript; Tomohiko Takasaki, Meng Ling Moi, Akira Kotaki performed real-time RT-PCR and performed the phylogenetic analysis; Haruka Uemura, Takashi Matono, Yoshihiro Fujiya, Momoko Mawatari, Nozomi Takeshita, Kayoko Hayakawa collected the data and participated in the concept of the manuscript; Shuzo Kanagawa, Norio Ohmagari revised the article for intellectual content. All authors read and critically revised the first as well as the subsequent and final drafts of this manuscript.

* Addendum:

The GenBank accession number of the partial Zika virus nucleotide sequence derived from a sample obtained from case 2 was added on 07 February 2014. 


\section{* Erratum:}

The title of this manuscript was initially wrong at the time of publication: 'Two cases of Zika fever imported from French Polynesia to Japan, December to January 2013'. The mistake was corrected on 31 January 2014.

\section{References}

1. Institut de Veille Sanitaire (InVS). Bulletin hebdomadaire international du 30 octobre au 5 novembre 2013 . N² 424 . Bulletin hebdomadaire international. 2013; 30-oct to 5-nov 2013; 424. French. Available from: http://www.invs.sante.fr/ Publications-et-outils/Bulletin-hebdomadaire-international/ Tous-les-numeros/2013/Bulletin-hebdomadaire-internationaldu-30-octobre-au-5-novembre-2013.-N-424

2. Zika and dengue: the Epidemic. Tahiti info. [Accessed 30 Jan 2014]. French. Available from: http://www.tahiti-infos.com/ Dengue-et-Zika-le-point-sur-l-epidemie_a91663.html

3. ProMED-mail. Zika virus - French Polynesia (03). Archive Number: 20140123.2227452. 23 January 2014. Available from: http://www.promedmail.org/direct.php?id=2227452

4. Lanciotti RS, Kosoy OL, Laven JJ, Velez JO, Lambert AJ, Johnson AJ, et al. Genetic and Serologic Properties of Zika Virus Associated with an Epidemic, Yap State, Micronesia, 2007. Emerg Infect Dis. 2008;14(8):1232-9. http://dx.doi.org/10.3201/eid1408.080287

5. Kuno G, Chang GJ, Tsuchiya KR, Karabatsos N, Cropp CB. Phylogeny of the genus Flavivirus. J Virol. 1998;72(1):73-83.

6. Heang V, Yasuda CY, Sovann L, Haddow AD, Travassos da Rosa AP, Tesh RB, et al. Zika virus infection, Cambodia, 2010. Emerg Infect Dis. 2012;18(2):349-51. http://dx.doi.org/10.3201/eid1802.111224

7. Dick GW, Kitchen SF, Haddow AJ. Zika virus. I. Isolations and serological specificity.Trans R Soc Trop Med Hyg. 1952;46(5):509-20. http://dx.doi.org/10.1016/0035-9203(52)90042-4

8. Haddow AD, Schuh AJ, Yasuda CY, Kasper MR, Heang V, Huy R, et al. Genetic characterization of Zika virus strains: geographic expansion of the Asian lineage. PLoS Negl Trop Dis. 2012;6(2):e1477. http://dx.doi.org/10.1371/journal.pntd.0001477

9. Duffy MR, Chen TH, Hancock WT, Powers AM, Kool JL, Lanciotti RS, et al. Zika virus outbreak on Yap Island, Federated States of Micronesia. N Engl J Med. 2009;360(24):2536-43. http://dx.doi.org/10.1056/NEJMoa0805715

10. ProMED-mail. ZIKA VIRUS - NEW CALEDONIA. Archive Number: 20140122.2224823. 22 January 2014. Available from: http:// www.promedmail.org/direct.php?id=2224823

11. Foy BD, Kobylinski KC, Chilson Foy JL, Blitvich BJ, Travassos da Rosa A, Haddow AD, et al. Probable non-vector-borne transmission of Zika virus, Colorado, USA. Emerg Infect Dis. 2011;17(5):880-2.

http://dx.doi.org/10.3201/eid1705.101939

12. Kwong JC, Druce JD, Leder K. Zika virus infection acquired during brief travel to Indonesia. Am J Trop Med Hyg. 2013;89(3):516-7. http://dx.doi.org/10.4269/ajtmh.13-0029

13. ProMED-mail. ZIKA VIRUS - CANADA ex THAILAND. Archive Number: 20130529.1744108. 29 March 2013. Available from: http://www.promedmail.org/direct.php?id=1744108

14. Tappe D, Rissland J, Gabriel M, Emmerich P, Günther S, Held G, Smola S, Schmidt-Chanasit J. First case of laboratoryconfirmed Zika virus infection imported into Europe, November 2013. Euro Surveill. 2014;19(4):pii=20685. Available online: http://www.eurosurveillance.org/ViewArticle. aspx?Articleld $=20685$

15. Hirayama T, Mizuno Y, Takeshita N, Kotaki A, Tajima S, Omatsu $\mathrm{T}$, et al. Detection of dengue virus genome in urine by real-time reverse transcriptase PCR: a laboratory diagnostic method useful after disappearance of the genome in serum. J Clin Microbiol. 2012;50(6):2047-52.

http://dx.doi.org/10.1128/JCM.06557-11 